\title{
In remembrance of the El Paso victims
}

\section{Lourdes Torres ${ }^{1}$}

Published online: 16 October 2019

(c) Springer Nature Limited 2019

As the academic quarter began this September at DePaul University in Chicago, I asked the students in my Constructing Latino Communities class, most of whom are Latino, to discuss the place of Latinos in US society today. This immediately stimulated a difficult conversation about the El Paso massacre. Students shared story after story of how this incident prompted anger, fear, sadness, and a sense of imminent threat. One student talked about being afraid for her family in Texas, another expressed apprehension about leaving her Chicago apartment for days after the shooting, yet another shared his family's reluctance to attend a neighborhood soccer match where most of the players and fans would be Mexican. Another, who heard about the shooting while on vacation in Fort Lauderdale, Florida, mentioned being overwhelmed with incredible sadness, crying uncontrollably and noticing with unease for the first time that she was in "Trump country."

It is clear that on August 3, 2019, when a 21-year-old male white supremacist drove 10 hours from the Dallas area to El Paso to kill Mexicans, he not only brutally gunned down twenty-two people and injured many more, but also contributed to the already heightened sense of anxiety experienced by Latinos across the United States today.

Many have been quick to indict the dehumanizing and hateful anti-Mexican, antiimmigrant rhetoric coming from the current administration as a direct catalyst for this horrific act of domestic terrorism. A manifesto published shortly before the attack and believed to be written by the killer declared, "This attack is a response to the Hispanic invasion of Texas," directly referencing language used by our current president, who routinely describes Mexicans and Central American migrants and refugees at the border as an invading force.

As we mourn those taken from us in this reprehensible act, it is important to remember that the actions of this homegrown terrorist are not only the result of the current political moment but are also part of a much longer anti-Mexican legacy. Violence against Mexicans has a long trajectory in the United States and has been particularly bloody in Texas. This history is documented in books such as William D. Carrigan and Clive Webb's Forgotten Dead: Mob Violence against Mexicans in

Lourdes Torres

1torres@depaul.edu

1 DePaul University, Chicago, IL, USA 
the United States, 1848-1928 (2013); The Injustice Never Leaves You: Anti-Mexican Violence in Texas (2018) by Monica Muñoz Martinez; and The Lynching of Mexicans in the Texas Borderlands (2018) by Nicholas Villanueva Jr.

And although the shooter's family disavowed his actions and declared they had no idea where their son picked up such hateful views, Michael Phillips and Betsy Friauf (https://www.jacobinmag.com/2019/08/patrick-crusius-texas-el-paso-massa cre-shooting-gun-laws) remind us that anti-Latino, anti-immigrant sentiment permeates the middle-class Dallas, Texas, suburb where he was raised. The textbooks in the schools he attended (and in many schools throughout the nation) are filled with texts and images that propagate a distorted history of Anglo-American and Mexican relations. The district where he was raised and the surrounding area are awash in politicians who have long trafficked in white supremacist, demographic hysteria and enacted punitive anti-Latino laws and regulations.

Three days after the El Paso massacre, hundreds of ICE agents descended on seven poultry plants in four cities in Mississippi and arrested 680 workers believed to be undocumented. This wreaked havoc across the community as families' lives were cruelly disrupted, adults desperately searched for missing and possibly arrested loved ones, and devastated children returned from their first day of school to empty homes. No company executives were arrested for hiring undocumented workers.

The intensified cruelty visited on Latino communities over these few days in early August added to the daily barrage of stories of children detained in cages, families separated, and increasingly punitive migration and refugee statutes and policies. This convergence bolsters the argument that historically, and currently, Latino lives are expendable and disposable. Like the shooting, these actions serve to terrorize not just their immediate victims, but Latinos and immigrants everywhere.

It is unquestionable that the current administration has added fuel to a simmering fire that combusted on August 3 in El Paso, Texas, forever changing the fates of those killed and injured as well as their families, friends, and community members. Clearly, as my students expressed, the repercussions of this hateful act are not limited to El Paso, Texas. Latinos across the country feel a target on their backs and a rising sense of anxiety and fear. As we struggle to unpack what these realities mean, and how we will respond to them, I ask that we recognize and remember our sisters and brothers who lost their lives in the atrocious tragedy in El Paso.

Rest in peace

Jordan Anchondo, 24, and Andre Anchondo, 23

Arturo Benavides, 60

Leonard Cipeda Campos, 41, and Maribel Hernandez, 56

Raul Flores, 77, and Maria Flores, 77

Jorge Calvillo García, 61

Adolfo Cerros Hernandez, 68, and Sara Esther Regalado, 66

Alexander Gerhard Hoffman, 66

David Alvah Johnson, 63

Luis Alfonzo Juarez, 90

María Eugenia Legarreta Rothe, 58

Elsa Libera Marquez, 57 
Ivan Hilierto Manzano, 46

Gloria Irma Marquez, 61

Margie Reckard, 63

Javier "Amir" Rodriguez, 15

Teresa Sánchez de Freitas, 82

Angelina Englisbee, 86

Juan Velázquez, 77

Publisher's Note Springer Nature remains neutral with regard to jurisdictional claims in published maps and institutional affiliations. 